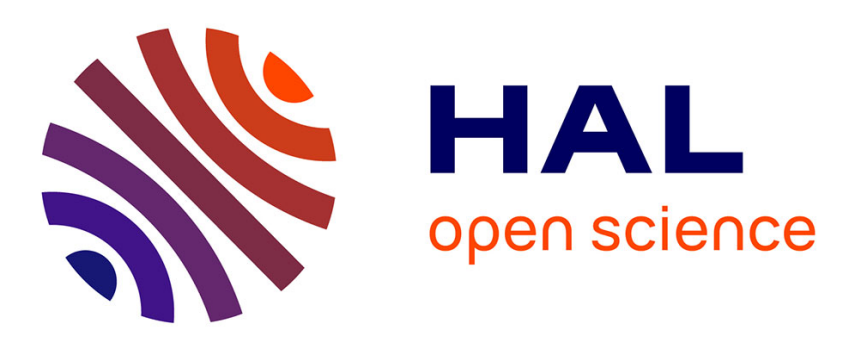

\title{
Molecular characterization of corsican isolates of citrus tristeza virus
}

Matilde Tessitori, Jean-Pierre Thermoz, Mario Davino, Salvatore Davino

\section{To cite this version:}

Matilde Tessitori, Jean-Pierre Thermoz, Mario Davino, Salvatore Davino. Molecular characterization of corsican isolates of citrus tristeza virus. II International Symposium on Citrus Biotechnology, Nov 2009, Catania, Italy. pp.1, 2009. hal-02824433

\section{HAL Id: hal-02824433 \\ https://hal.inrae.fr/hal-02824433}

Submitted on 6 Jun 2020

HAL is a multi-disciplinary open access archive for the deposit and dissemination of scientific research documents, whether they are published or not. The documents may come from teaching and research institutions in France or abroad, or from public or private research centers.
L'archive ouverte pluridisciplinaire HAL, est destinée au dépôt et à la diffusion de documents scientifiques de niveau recherche, publiés ou non, émanant des établissements d'enseignement et de recherche français ou étrangers, des laboratoires publics ou privés. 


\section{MOLECULAR CHARACTERIZATION OF CORSICAN ISOLATES OF CITRUS TRISTEZA VIRUS}

Matilde TESSITORI ${ }^{1}$, Jean Pierre THERMOZ2 ${ }^{2}$ Mario DAVINO ${ }^{1}$, Salvatore DAVINO ${ }^{3}$

1 DiSTeF, Plant pathology Sect., University of Catania, Catania, Italy; 2 Unité Genetique et Ecophysiologie de la Qualite des Agrumes-GEQA, INRA, San Giuliano-Corse, France; ${ }^{3}$ SENFIMIZO, Plant pathology and microbiology Sect., University of Palermo, Italy

e-mail:mtessitori@unict.it

\section{INTRODUCTION}

Tristeza disease, caused by the Citrus tristeza virus (CTV), is the most important viral disease for almost all citrus species. Syndromes and symptoms expression depend on the interactions of factors involved in the pathosystem, host-strain-rootstock-climate-vector. Several strains of CTV have been studied all over the world. Two Corsican isolates have been previously characterized, $\mathrm{K}$ strain from Marumi kumquat, known to be symptomless on Mexican lime, and Cal-1 from calamondin inducing stem pitting. No sequence data are published or available in GenBank (1).



\section{FIELD OBSERVATIONS}

Two new strains of CTV were recently found in Corsica during routine survey in citrus orchards. The isolates, named as LA5 and $\mathrm{CO}_{3}$, were detected in two different orchards of $\mathbf{4 0}$ year old Clementine on sour orange trees that did not show evident decay. A mild decline, observed in few trees of both field, was related by the growers to Phytophthora spp. infections, a common pathogen in the area. No other symptoms ascribable to tristeza, such as honeycombing or stem-pitting, were registered in the trees.

\section{MOLECULAR CHARACTERIZATION}

After the preliminary detection by DAS-ELISA, the two isolates $\mathrm{CO} 3$ and LA5 were identified and characterized by molecular tools. Total RNA were extracted by using TRIZOL ${ }^{\circledR}$ (Invitrogen) method from $100 \mathrm{mg}$ of leaf tissue. Two $\mu \mathrm{l}$ of suspension were used for RT-PCR with P20 gene specific primers (CP gene). The Spanish T385 and Italian DS1 isolates were used in the reaction as positive control (2). PCR fragments (540 bp) were characterized by SSCP analysis, cloned in an apCR2.1-TOPO vector Kit (TOPO-TA Cloning, Invitrogen) and sequenced in both directions. The sequences obtained were aligned with those of related isolates using the CLUSTAL W program and then analyzed for phylogenetic relationship using the MEGA based neighbour-joining method with a 1,000 replicate bootstrap value.

\section{RESULTS AND DISCUSSION}

CTV presence was confirmed both in $\mathrm{CO3}$ and LA5 samples by RT-PCR. The obtained amplicons showed expected size of $540 \mathrm{nt}$. (Fig. 2a) and evidenced two different SSCP profile (Fig. 2b). Sequences analysis pointed out high similarity between $\mathrm{CO} 3$ and LA5 $(98 \%)$ and evidenced their high similarity with the isolate NZRB-G90 from New Zeland (GenBank ACc. N. FJ525432), 98\% and 97\% respectively.

Compared to previously described groups of CTV isolates (mild, severe, atypical), phylogenetic analysis has defined a new cluster including both LA5 and $\mathrm{CO} 3$ (Fig. 3 ). Given the absence in the literature and in GenBank of sequence data of the $K$ strain is now impossible to correlate the new Corsican isolates with the asymptomatic one. This comparison is however necessary in order to hypothesize phylogenetic relationships or patterns of disease spread in the field.
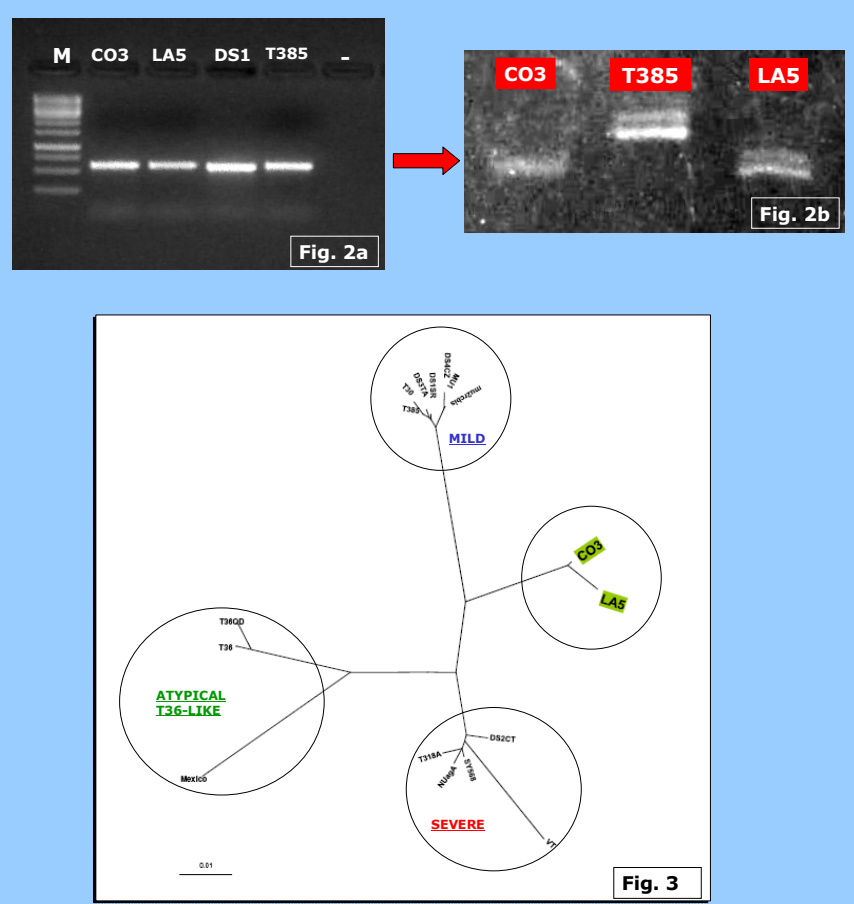